Jurnal Semarak,Vol.4,No.1,Februari 2021, Hal (41-50)

@ Prodi Manajemen Fakultas Ekonomi Universitas Pamulang

\title{
FAKTOR-FAKTOR YANG MEMPENGARUHI KEAKTIFAN BELAJAR MAHASISWA TINGKAT 1 PROGRAM STUDI MANAJEMEN UNIVERSITAS PAMULANG
}

\author{
Ibrahim Bali Pamungkas, Wahyu Andri Wibowo, Angga Juanda \\ Staf Pengajar Fakultas Ekonomi Universitas Pamulang \\ 1) dosen universitas pamulang,email:dosen01015@unpam.ac.id \\ ${ }^{2)}$ dosen universitas pamulang, email: wahyuandri.wibowo@yahoo.com \\ ${ }^{3)}$ dosen universitas pamulang, email: dosen02240@ unpam.ac.id
}

\begin{abstract}
ABSTRAK
Tujuan dalam penelitian ini adalah mendeskripsikan factor - faktor yang mempengaruhi keaktifan belajar mahasiswa tingkat 1 program studi manajemen Universitas Pamulang, Subjek penelitian ini adalah mahasiswa untuk tingkat 1 program studi manajemen Universitas Pamulang. Penelitian berikut merupakan penelitian kuantitatif jenis deskriptif. Metode pengumpulan data dengan menggunakan observasi dan kuesioner. Teknik pengambilan sampel dengan menggunakan rumus Slovin. Keabsahan data dalam penelitian ini menggunakan Uji Validitas, Uji Reliabilitas, dan Uji Asumsi Klasik .Hasil penelitian menunjukkan bahwa (1) Keaktifan Belajar pada mahasiswa tingkat 1 program studi manajemen Universitas Pamulang sudah Sangat Baik, (2) Terdapat pengaruh secara bersamasama antara Faktor Internal $\left(\mathrm{X}_{1}\right)$ dan Faktor Eksternal $\left(\mathrm{X}_{2}\right)$ Terhadap Keaktifan Belajar (Y) pada mahasiswa tingkat 1 program studi manajemen Universitas Pamulang, (3) Faktor Internal yang sangat mempengaruhi Keaktifan Belajar mahasiswa adalah Jasmani sedangkan Faktor Eksternal yang sangat mempengaruhi Keaktifan Belajar mahasiswa adalah Tempat.
\end{abstract}

\section{Kata kunci: Faktor Internal, Faktor Eksternal, Keaktifan Belajar}

\begin{abstract}
This study aims to describe the factors that affect the learning activeness of the 1st level students of the Pamulang University management study program. The subjects of this study were students of level 1 management study program at Pamulang University. This research is a descriptive quantitative research. Methods of data collection using observations and questionnaires. The sampling technique used the Slovin formula. The validity of the data in this study used the validity test, reliability test, and classical assumption test. The results showed that (1) Learning Activeness at level 1 students of the Pamulang University management study program was very good, (2) There was a joint influence between Internal Factors (X1) and External Factors (X2) on Learning Activeness (Y) in Level 1 students of the Pamulang University management study program, (3) Internal factors that greatly influence student learning activity are physical, while external factors that greatly affect student learning activeness are place.
\end{abstract}

Keywords: Internal Factors, External Factors, Learning Activeness

I. PENDAHULUAN

A. Latar Belakang
Pembelajaran jadi prioritas yang senantiasa memperoleh atensi spesial oleh segala bangsa 
serta negeri di dunia. Pembelajaran tersebut sangat mempunyai peranan berarti didalam kehidupan bermasyarakat. Perihal ini sebab lewat pembelajaran, negeri bisa meningkatkan kemampuan bangsanya. Tidak hanya itu, pembelajaran ialah salah satu proses mengganti perilaku serta tingkah laku seorang lewat belajar mengajar serta pelatihan. Pembelajaran ialah usaha siuman yang dicoba guna membimbing serta memusatkan pertumbuhan anak menuju berusia. Berusia yang dimaksudkan merupakan bertanggung jawab pada diri sendiri, keluarga, warga, bangsa, serta negeri.

Sistem pembelajaran yang mengedepankan perbandingan kebutuhan dari orang jadi makna peradaban baru yang memerlukan kepemimpinan yang mewujudkan nilai baru. Di masa globalisasi ini meningkatkan kerjasama warga yang demokratis serta berpartisipasi aktif. Pembelajaran yang demokratis merupakan pembelajaran dengan memakai tata cara yang bisa menggali keahlian siswa sehingga bisa berfungsi aktif dengan tidak mengesampingkan perbandingan keahlian intelektual, belajar, perilaku, serta minatnya.

Sepanjang proses pendidikan mahasiswa dituntut aktifitasnya buat mencermati, mencermati, serta mengolah modul pelajaran yang di informasikan oleh dosen yang bersangkutan, selain itu sangat membolehkan para mahasiswa membagikan timbal balik berbentuk persoalan, gagasan benak, perasaan, keinginannya. Dosen sebaiknya sanggup membina rasa keberanian, kemauan mahasiswa, buat itu sebaiknya mahasiswa merasa nyaman, aman serta kondusif dalam belajar. Kedudukan dosen dalam pendidikan mahasiswa aktif merupakan bagaikan fasilitator serta pembimbing mahasiswa yang berikan bermacam kemudahan mahasiswa dalam belajar dan sanggup mendesak mahasiswa buat belajar seoptimal bisa jadi.

"Keaktifan belajar merupakan kegiatan yang bertabiat raga ataupun mental (Sardiman, 2001)" sepanjang aktivitas belajar kedua kegiatan tersebut wajib terpaut, sehingga hendak menciptakan kegiatan belajar yang maksimal. Di dalam diri mahasiswa ada kekuatan yang jadi energi penggerak keaktifan ialah motivasi ataupun dorongan. Dorongan itu bukan cuma dari aspek diri mahasiswa sendiri namun pula dari area dimana mahasiswa tersebut belajar. Aspek yang mendesak melaksanakan suatu keaktifan seorang siswa umumnya tidak ditetapkan oleh sesuatu aspek tunggal saja, hendak namun bermacam aspek yang mempengaruhinya. Mahasiswa dikatakan mempunyai keaktifan apabila ditemui identitas sikap semacam: kerap bertanya kepada dosen ataupun mahasiswa lain terpaut pelajaran, mengerjakan tugas- tugas yang diberikan dosen, sanggup menanggapi persoalan, serta bahagia diberi tugas belajar.

Bersumber pada pengamatan sepanjang bulan Agustus- Januari pada mahasiswa tingkatan 1 Universitas Pamulang Program Riset Manajemen tahun ajaran 2019/ 2020, masih banyak mahasiswa yang hadapi kesusahan belajar. Perihal ini disebabkan pada dikala pendidikan berlangsung, mahawsiswa kurang konsentrasi pada modul pelajaran. Perihal ini bisa dilihat kala proses pendidikan, mahasiswa cenderung kerap mengajak mahasiswa lain buat bermain serta berbincang- bincang

Pada kegiatan belajar, keahlian mahasiswa buat mengerjakan tugas, berpartisipasi secara aktif dalam aktivitas belajar, serta mencermati ialah perlengkapan sangat berarti buat memperkirakan keberhasilan mereka di kampus. Belajar jadi salah satu tugas serta kewajiban mahasiswa supaya bisa menggapai keberhasilan. Sukses ataupun tidaknya mahasiswa dalam belajar diakibatkan sebagian aspek. Aspek tersebut bisa berasal dari dalam diri mahasiswa (internal) serta dari luar diri mahasiswa (eksternal).

Aspek internal yang pengaruhi belajar mahasiswa merupakan kesehatan. Apabila seorang senantiasa tidak sehat, sakit kepala, demam, pilek, batuk serta sebagainya, bisa menyebabkan tidak bergairah buat belajar. Demikian pula halnya bila kesehatan rohani (jiwa) kurang baik, misalnya hadapi kendala benak, perasaan kecewa sebab konflik dengan sahabat dekatnya, orang tua ataupun sebab karena yang lain, ini bisa mengusik ataupun kurangi semangat belajar. Ada pula aspek eksternal yang pengaruhi belajar siswa bisa berasal dari keluarga, sekolah, warga, serta area dekat.

Bersumber pada latar balik permasalahan yang telah sampaikan tadinya, periset tertarik 
buat mengenali aspek-aspek yang pengaruhi keaktifan belajar mahasiswa. Sehabis mengenali faktor-faktor yang pengaruhi keaktifan belajarnya, hingga diharapkan mahasiswa bisa mengembangakan partisipasinya serta keaktifannya dalam belajar. Oleh karena itu, judul pada penelitian ini adalah "Faktor-faktor yang mempengaruhi keaktifan belajar mahasiswa tingkat 1 Program Studi Manajemen Universitas Pamulang".

\section{B. Rumusan Masalah}

Berdasarkan latar belakang diatas, dapat dirumuskan masalahnya sebagai berikut:

$$
\text { 1. Bagaimana keaktifan belajar }
$$
mahasiswa tingkat 1 program studi manajemen Universitas Pamulang?

2. Seberapa besar pengaruh factor internal dan eksternal terhadap keaktifan belajar mahasiswa tingkat 1 program studi manajemen Universitas Pamulang?

3. Apa saja factor internal dan factor eksternal yang mempengaruhi keaktifan belajar mahasiswa tingkat 1 program studi manajemen Universitas Pamulang?

\section{TINJAUAN PUSTAKA}

\section{A. Keaktifan Belajar}

"Keaktifan belajar adalah aktifitas yang bersifat fisik maupun mental (Sardiman, 2001)". Sepanjang aktivitas belajar kedua kegiatan tersebut wajib terpaut, sehingga hendak menciptakan kegiatan belajar yang maksimal.

\section{B. Belajar}

"Belajar artinya berusaha memperoleh kepandaian atau ilmu; berlatih; dan berubah tingkah laku atau tanggapan yang disebabkan oleh pengalaman (Poerwadarminta, 2002)."

"Menurut Mohammad Surya (2004) menyatakan bahwa dalam psikologi pendidikan, belajar diartikan sebagai suatu proses usaha yang dilakukan individu untuk memperoleh suatu perubahan perilaku yang baru secara keseluruhan, sebagai hasil pengalaman individu itu sendiri dalam interaksi dengan lingkungannya."

\section{Kerangka Berpikir}

Berdasarkan latar belakang dan permasalahan keaktifan belajar mahasiswa tingkat 1 program studi manajemen Universitas Pamulang. Keaktifan belajar mahasiswa di asumsikan dapat di tingkatkan apabila manajemen pembinaan sumber daya manusia dapat dioptimalkan sehingga mampu meningkatkan prestasi belajar mahasiswa sebagai upaya mewujudkan tercapainya tujuan.

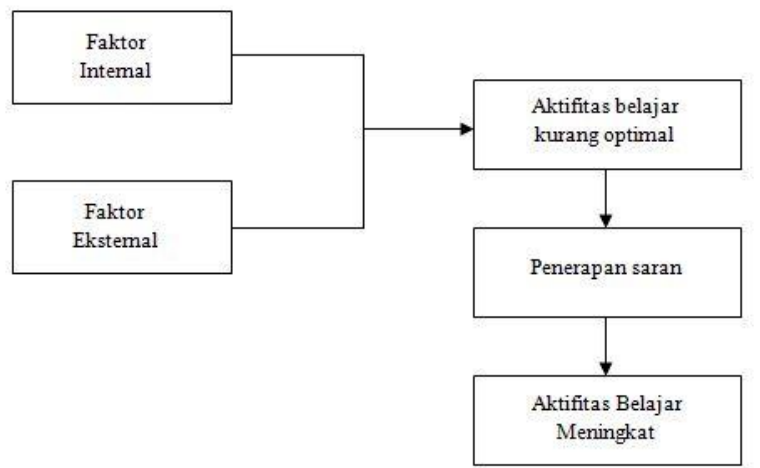

Gambar Kerangka Berpikir

\section{Hipotesis}

"Menurut Sugiyono (2016) Hipotesis merupakan jawaban sementara terhadap rumusan penelitian, setelah peneliti mengemukakan landasan teori dan kerangka berpikir, Perumusan hipotesis penelitian adalah sebagai berikut:"

$\mathbf{H 1}=\mathrm{Ho}_{1}$ : Tidak terdapat pengaruh factor internal $\left(\mathrm{X}_{1}\right)$ dan factor eksternal $\left(\mathrm{X}_{2}\right)$ terhadap keaktifan belajar (Y).

$\mathrm{Ha}_{1}$ : Terdapat pengaruh factor internal $\left(\mathrm{X}_{1}\right)$ dan factor eksternal $\left(\mathrm{X}_{2}\right)$ terhadap keaktifan belajar (Y).

\section{METODE PENELITIAN}

"Pengertian metode penelitian menurut Sugiyono (2014) adalah cara ilmiah untuk mendapatkan data yang valid dengan tujuan dapat ditemukan, dibuktikan, dikembangkan suatu pengetahuan tertentu sehingga pada gilirannya dapat digunakan untuk memahami, memecahkan dan mengantisipasi masalah. Metode penelitian yang digunakan adalah metode kuantitatif." "Menurut Sugiyono (2016), Metode kuantitatif dapat diartikan sebagai metode penelitian yang berlandaskan pada filsafat positivisme, digunakan untuk meneliti pada populasi atau sample tertentu, pengumpulan data menggunakan instrumen penelitian, analisis data bersifat 
kuantitatif/statistik, dengan tujuan untuk menguji hipotesis yang telah ditetapkan".

Jenis penelitian ini bersifat asosiatif, menurut Sugiyono (2014) yaitu: "Penelitian yang bertujuan untuk mengetahui pengaruh atau hubungan antara dua variabel atau lebih". Lebih lanjut Sugiyono (2014) menjelaskan "Dengan penelitian asosiatif maka dapat dibangun suatu teori yang berfungsi untuk menjelaskan, meramalkan dan mengontrol suatu gejala". Pembahasan deskriptif ini untuk menjabarkan objek penelitian berdasarkan variabel yang telah ditetapkan dari hasil penelitian yang diharapkan bisa mengetahui variabel yang perlu diperbaiki untuk kondisi variabel juga menjadi lebih baik dan yang sudah baik untuk ditingkatkan. Pembahasan verifikatif yang dilakukan pada tahap ini bertujuan untuk membahas perihal pengaruh dari signifikansinya. Selain itu pembahasan dilakukan untuk mengetahui adanya fenomena yang ada dilapangan yang disesuaikan dengan hasil pengolahan data. Desain riset ialah bagian dari perencanaan riset yang membuktikan riset untuk memandang apakah riset yang direncanakan sudah mempunyai validitas internal serta validitas eksternal secara komprehensif. Dilihat rumusan dan tujuan sebelumnya, metode penelitian yang digunakan penulis adalah metode deskriptif.

\section{HASIL DAN PEMBAHASAN \\ A. Hasil \\ 1. Karakter Responden \\ Jenis Kelamin}

Instrumen Pertama dengan penilaian sebesar 1528 dengan rata-rata penilaian 4,28 termasuk kategori Sangat Baik.

Instrumen kedua dengan penilaian sebesar 1527 dengan rata-rata penilaian 4,28 termasuk kategori Sangat Baik.

2) Keadaan Fisik (pancaindera)

Untuk indikator, diperoleh 2 instrumen pernyataan dapat di deskripsikan sebagai berikut:

Instrumen ketiga dengan penilaian sebesar 1461 dengan rata-rata penilaian 4,09 termasuk kategori Baik.

Instrumen keempat dengan penilaian sebesar 906 dengan rata-rata penilaian 2,54 termasuk kategori Tidak Baik.

3) Perhatian

Untuk indikator, diperoleh 2 instrumen pernyataan dapat di deskripsikan sebagai berikut:

Instrumen kelima dengan penilaian sebesar 1362 dengan rata-rata penilaian 3,82 termasuk kategori Baik.

Instrumen keenam dengan penilaian sebesar 1495 dengan rata-rata penilaian 4,19 termasuk kategori Baik.

4) Tanggapan

Untuk indikator, diperoleh 2 instrumen pernyataan dapat di deskripsikan sebagai berikut:

Instrumen ketujuh dengan penilaian sebesar 1441 dengan rata-rata penilaian 4,04 termasuk kategori Baik.

Instrumen kedelapan dengan penilaian sebesar 931 dengan rata-rata penilaian

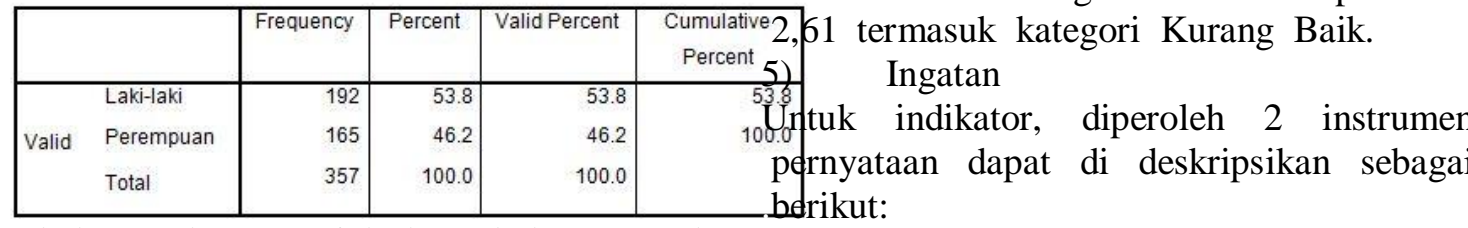

Tabel tersebut menjelaskan bahwa untuk Instrumen kesembilan dengan penilaian jenis kelamin laki-laki sebanyak 197 responden $53,8 \%$ dan untuk jenis kelamin perempuan sebanyak 165 responden $46,2 \%$. Kesimpulannya bahwa responden berjenis kelamin laki-laki mendominasi.

\section{Analisa Deskriptif}

a. Analisa Faktor Internal

1) Jasmani

Untuk indikator, diperoleh 2 instrumen pernyataan dapat di deskripsikan sebagai berikut: sebesar 841 dengan rata-rata penilaian 2,36 termasuk kategori Tidak Baik.

Instrumen kesepuluh dengan penilaian sebesar 1277 dengan rata-rata penilaian 3,58 termasuk kategori Baik.

Kesimpulan penjelasan diatas adalah, instrumen variabel Faktor Internal $\left(\mathrm{X}_{1}\right)$ menunjukkan total penilaian sebesar 12769 dengan rata-rata penilaian 3,58 termasuk kategori Baik, serta penilaian jawaban Sangat Setuju (SS) sebesar 20,73\%, Setuju (S) sebesar 42,04\%, Ragu-Ragu (RR) 
sebesar 16,89\%, Tidak Setuju (TS) sebesar $14,85 \%$ dan Sangat Tidak Setuju (STS) $5,49 \%$.

Variabel Faktor Internal $\left(\mathrm{X}_{1}\right)$ yang perlu ditingkatkan adalah pada instrumen kesembilan dengan penilaian rata-rata terendah sebesar 2,36. Pada instrumen ini mahasiswa harus rajin dalam mengerjakan tugas-tugas yang sudah di berikan oleh dosen.

\section{b. Analisa Faktor Eksternal \\ 1) Dosen}

Untuk indikator, diperoleh 3 instrumen pernyataan dapat di deskripsikan sebagai berikut:

Instrumen pertama dengan penilaian sebesar 1496 dengan rata-rata penilaian 4,19 termasuk kategori Baik.

Instrumen kedua dengan penilaian sebesar 1566 dengan rata-rata penilaian 4,39 termasuk kategori Sangat Baik.

Instrumen ketiga dengan penilaian sebesar 1417 dengan rata-rata penilaian 3,97 termasuk kategori Baik.

2) Teman sebaya

Untuk indikator, diperoleh 2 instrumen pernyataan dapat di deskripsikan sebagai berikut:

Instrumen keempat dengan penilaian sebesar 1480 dengan rata-rata penilaian 4,15 termasuk kategori Baik.

Instrumen kelima dengan penilaian sebesar 1369 dengan rata-rata penilaian 3,83 termasuk kategori Baik.

3) Tempat

Untuk indikator, diperoleh 2 instrumen pernyataan dapat di deskripsikan sebagai berikut:

Instrumen keenam dengan penilaian sebesar 1446 dengan rata-rata penilaian 4,05 termasuk kategori Baik.

Instrumen ketujuh dengan penilaian sebesar 1674 dengan rata-rata penilaian 4,69 termasuk kategori Sangat Baik.

4) Fasilitas

Untuk indikator, diperoleh 3 instrumen pernyataan dapat di deskripsikan sebagai berikut:

Instrumen kedelapan dengan penilaian sebesar 1620 dengan rata-rata penilaian 4,54 termasuk kategori Sangat Baik.
Instrumen kesembilan dengan penilaian sebesar 1462 dengan rata-rata penilaian 4,10 termasuk kategori Baik.

Instrumen kesepuluh dengan penilaian sebesar 1482 dengan rata-rata penilaian 4,15 termasuk kategori Sangat Baik.

Kesimpulan penjelasan diatas dapat disimpulkan bahwa, instrumen variabel Faktor Eksternal $\left(\mathrm{X}_{2}\right)$ menunjukkan total penilaian sebesar 15012 dengan rata-rata penilaian 4,21 termasuk kategori Sangat Baik, serta penilaian jawaban Sangat Setuju (SS) sebesar 36,11 \%, Setuju (S) sebesar 51,57\%, Ragu-Ragu (RR) sebesar 9,58\%, Tidak Setuju (TS) sebesar 2,21\% dan Sangat Tidak Setuju (STS) sebesar $0,53 \%$.

Variabel Faktor Belajar $\left(\mathrm{X}_{2}\right)$ perlu peningkatan untuk instrumen no. 5 memperoleh penilaian rata-rata paling rendah dengan nilai 3,83 . Pada instrumen ini agar lebih sering mengingatkann temannya agar masuk ke kampus.

c. Analisa Keaktifan Belajar

1) Visual Activities

Untuk indikator, diperoleh 1 instrumen pernyataan dapat di deskripsikan sebagai berikut:

Instrumen pertama dengan penilaian sebesar 1602 dengan rata-rata penilaian 4,49 termasuk kategori Sangat Baik.

\section{2) Oral Activities}

Untuk indikator, diperoleh 1 instrumen pernyataan dapat di deskripsikan sebagai berikut:

Instrumen kedua dengan penilaian sebesar 1428 dengan rata-rata penilaian 4,00 termasuk kategori Baik.

3) Listening Activities

Untuk indikator, diperoleh 1 instrumen pernyataan dapat di deskripsikan sebagai berikut:

Instrumen ketiga dengan penilaian sebesar 1597 dengan rata-rata penilaian 4,47 termasuk kategori Sangat Baik.

\section{4) Writing Activities}

Untuk indikator, diperoleh 1 instrumen pernyataan dapat di deskripsikan sebagai berikut:

Instrumen keempat dengan penilaian sebesar 1601 dengan rata-rata penilaian 4,48 termasuk kategori Sangat Baik.

5) Drawing Activities 
Untuk indikator, diperoleh 1 instrumen pernyataan dapat di deskripsikan sebagai berikut:

Instrumen kelima dengan penilaian sebesar 1603 dengan rata-rata penilaian 4,49 termasuk kategori Sangat Baik.

6) Motor Activities

Untuk indikator, diperoleh 1 instrumen pernyataan dapat di deskripsikan sebagai berikut:

Instrumen keenam dengan penilaian sebesar 1356 dengan rata-rata penilaian 3,80 termasuk kategori Baik.

7) Mental Activities

Untuk indikator, diperoleh 2 instrumen pernyataan dapat di deskripsikan sebagai berikut:

Instrumen ketujuh dengan penilaian sebesar 1515 dengan rata-rata penilaian 4,24 termasuk kategori Sangat Baik.

Instrumen kedelapan dengan penilaian sebesar 1410 dengan rata-rata penilaian 3,95 termasuk kategori Baik.

8) Emotional Activities

Untuk indikator, diperoleh 2 instrumen pernyataan dapat di deskripsikan sebagai berikut:

Instrumen kesembilan dengan penilaian sebesar 1447 dengan rata-rata penilaian 4,05 termasuk kategori Baik.

Instrumen kesepuluh dengan penilaian sebesar 1507 dengan rata-rata penilaian 4,22 termasuk kategori Sangat Baik.

Kesimpulan penjelasan diatas dapat disimpulkan bahwa, instrumen variabel

Keaktifan Belajar (Y) menjukkan total penilaian sebesar 15066 dengan rata-rata penilaian 4,22 termasuk kategori Baik, serta penilaian jawaban Sangat Setuju (SS) sebesar 40,90\%, Setuju (S) sebesar 44,26\%, Ragu-Ragu (RR) sebesar $11,57 \%$, Tidak Setuju (TS) sebesar 2,52\% dan Sangat Tidak Setuju (STS) sebesar 0,76\%. Variabel Keaktifan Belajar (Y) perlu peningkatan untuk instrumen no. 6 memperoleh penilaian rata-rata paling rendah dengan nilai 3,80. Pada instrumen ini mahasiswa harus aktif jika ada soal hitung-hitungan.

\section{Uji Validitas}

"Uji Validasi dilakukan untuk mengukur sah atau tidaknya indikator atau kuesioner dari masing-masing variabel. Pengujian dilakukan dengan membandingkan $\mathrm{r}_{\text {hitung }}$ dan $\mathrm{r}_{\text {tabel. }}$.

a. Uji Validitas Variabel Faktor Internal $\left(\mathrm{X}_{1}\right)$

Tabel Validitas $\mathrm{X}_{1}$

\begin{tabular}{|c|l|c|c|}
\hline No & \multicolumn{1}{|c|}{$\mathbf{R}_{\text {Hitung }}$} & $\mathbf{R}_{\text {Tabel }}$ & Ket \\
\hline 1 & 0.410 & 0.104 & Valid \\
\hline 2 & 0.415 & 0.104 & Valid \\
\hline 3 & 0.464 & 0.104 & Valid \\
\hline 4 & 0.454 & 0.104 & Valid \\
\hline 5 & 0.554 & 0.104 & Valid \\
\hline 6 & 0.445 & 0.104 & Valid \\
\hline 7 & 0.546 & 0.104 & Valid \\
\hline 8 & 0.451 & 0.104 & Valid \\
\hline 9 & 0.473 & 0.104 & Valid \\
\hline 10 & 0.583 & 0.104 & Valid \\
\hline
\end{tabular}

Tabel diatas menjelaskan bahwa pernyataan setiap instrumen Faktor Internal $\left(\mathrm{X}_{1}\right)$ setiap item menyatakan valid.

b. Uji Validitas Variabel Faktor Eksternal $\left(\mathrm{X}_{2}\right)$

Tabel Validitas $\mathrm{X}_{2}$

\begin{tabular}{|c|l|c|c|}
\hline No & \multicolumn{1}{|c|}{$\mathbf{R}_{\text {Hitung }}$} & $\mathbf{R}_{\text {Tabel }}$ & Ket \\
\hline 1 & 0.619 & 0.104 & Valid \\
\hline 2 & 0.621 & 0.104 & Valid \\
\hline 3 & 0.683 & 0.104 & Valid \\
\hline 4 & 0.673 & 0.104 & Valid \\
\hline 5 & 0.739 & 0.104 & Valid \\
\hline 6 & 0.715 & 0.104 & Valid \\
\hline 7 & 0.587 & 0.104 & Valid \\
\hline 8 & 0.637 & 0.104 & Valid \\
\hline 9 & 0.695 & 0.104 & Valid \\
\hline 10 & 0.706 & 0.104 & Valid \\
\hline
\end{tabular}

Tabel diatas menjelaskan bahwa pernyataan setiap instrumen Faktor Eksternal $\left(\mathrm{X}_{2}\right)$ setiap item menyatakan valid.

c. Uji Validitas Variabel Keaktifan Belajar (Y)

Tabel Validitas $\mathrm{Y}$

\begin{tabular}{|c|l|c|c|}
\hline No & \multicolumn{1}{|c|}{$\mathbf{R}_{\text {Hitugg }}$} & $\mathbf{R}_{\text {Tabel }}$ & Ket \\
\hline 1 & 0.687 & 0.104 & Valid \\
\hline 2 & 0.606 & 0.104 & Valid \\
\hline 3 & 0.744 & 0.104 & Valid \\
\hline 4 & 0.661 & 0.104 & Valid \\
\hline 5 & 0.580 & 0.104 & Valid \\
\hline 6 & 0.727 & 0.104 & Valid \\
\hline 7 & 0.729 & 0.104 & Valid \\
\hline 8 & 0.722 & 0.104 & Valid \\
\hline 9 & 0.706 & 0.104 & Valid \\
\hline 10 & 0.703 & 0.104 & Valid \\
\hline
\end{tabular}

Tabel diatas menjelaskan bahwa pernyataan setiap instrumen Keaktifan Belajar (Y) setiap item menyatakan valid. 


\section{Uji Reliabilitas}

"Uji reliabilitas bertujuan untuk mengetahui sejauh mana pengukuran yang telah dilakukan dalam penelitian ini dapat dipercaya atau dapat diandalkan. Nilai untuk menentukan reliabilitas suatu instrumen adalah nilai Cronbach's Alpha lebih besar dari 0,60."

Tabel Reliabilitas

\begin{tabular}{|c|c|c|}
\hline Variabel & $\begin{array}{c}\text { Cronbach's } \\
\text { Alpha }\end{array}$ & Nilai \\
\hline $\mathrm{X}_{1}$ & 0.609 & 0.60 \\
\hline $\mathrm{X}_{2}$ & 0.861 & 0.60 \\
\hline $\mathrm{Y}$ & 0.874 & 0.60 \\
\hline
\end{tabular}

Berdasarkan tabel diatas dapat dilihat bahwa untuk masing-masing pernyataan seluruh item terbukti dapat di percaya.

\section{Uji Asumsi Klasik}

a. Uji Normalitas

"Uji Normalitas Merupakan salah satu uji yang digunakan untuk mengetahui apakah berdistribusi normal atau tidak dalam model regresi, variable independent dan variable dependen."

Tabel Normalitas

One-Sample Kolmogorov-Smirnov Test

\begin{tabular}{|ll|r|}
\hline & & $\begin{array}{r}\text { Unstandardized } \\
\text { Residual }\end{array}$ \\
\hline $\mathrm{N}$ & Mean & 357 \\
Normal Parameters & a, & .0000000 \\
& Std. Deviation & 3.67942677 \\
MostExtreme Differences & Absolute & .044 \\
& Positive & .044 \\
Kolmogorov-Smirnov Z & Negative & -038 \\
Asymp. Sig. (2-tailed) & & .839 \\
\hline
\end{tabular}

Dari hasil uji Normalitas dengan metode

Kolmogorov-Smirnov di atas, diperoleh besarnya nilai Test Statistic KolmogorovSmirnov adalah 0,839 dan nilai Sig 0,483. Nilai signifikansi lebih besar dari 0,05 maka Ho diterima yang berarti data residual berdistribusi normal.

b. Uji Heterokedaktsitas

Heterokedastisitas menguji terjadinya perbedaan variance residual suatu periode pengamatan ke periode pengamatan yang lain.

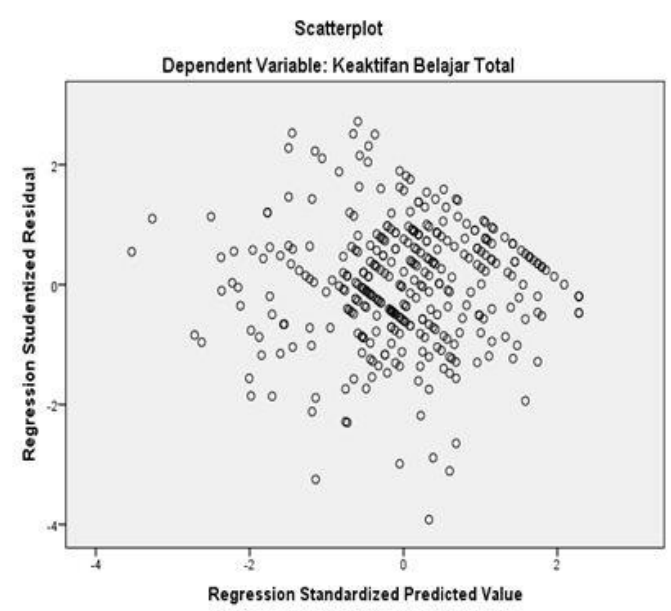

Gambar Heterokedaktisitas

Dari gambar Scatterplot di atas menunjukkan bahwa titik-titik menyebar di atas dan dibawah angka 0 pada sumbu $\mathrm{Y}$ serta penyebaran titik-titik data tidak berpola, maka dapat disimpulkan bahwa tidak terjadi heteroskedastisitas.

c. Uji Multikolinieritas

"Uji multikolinieritas diperlukan untuk mengetahui ada tidaknya variabel independen yang memiliki kemiripan antar variabel independen dalam suatu model."

Tabel Multikolinieritas

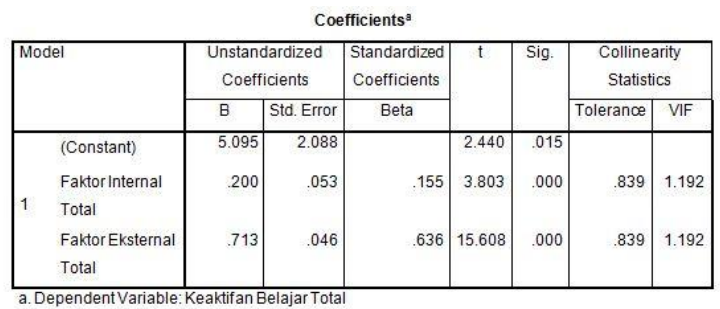

Dari tabel di atas menunjukkan bahwa, dari masing-masing variabel nilai Tolerance dan VIF, terlihat tidak ada nilai Toleransi di bawah nilai 0,10. Dan juga ditunjukkan dengan nilai VIF tidak melewati nilai 10 . Dengan menggunakan parameter ini, tidak terbukti terjadi multikolinieritas.

d. Uji Autokorelasi

"Uji autokorelasi bertujuan menguji apakah dalam model regresi linier ada korelasi antara kesalahan pengganggu pada periode $\mathrm{t}$ dengan kesalahan pengganggu pada periode t-1 (sebelumnya)."

Tabel Autokorelasi 


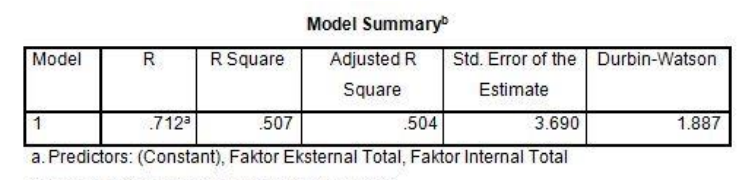

b. Dependent Variable: Keaktifan Belajar Total

Nilai Durbin sebesar 1,887 hendak dibanding dengan nilai tabel Durbin Watson dengan signifikansi $5 \%$ jumlah sampel 357 responden dan jumlah variabel bebas (independen) $2(\mathrm{~K}=2)$. Hasil nilai DU dan DL yang didapatkan dari tabel Durbin Watson adalah:

$\mathrm{DL}=1,82150$ dan $\mathrm{DU}=1,83264$.

Berdasarkan hasil pengambilan keputusan berada pada du $<$ d $<4$-du $(1,83264<$ $1,887<2,16736)$. Oleh karena nilai DW (Durbin Watson) sebesar 1,887 lebih besar dari batas atas (DU) 1,83264 dan kurang dari 2,16736 (4-du), maka dapat disimpulkan bahwa hasil penelitian menyatakan tidak ada autokorelasi positif dan negatif atau dapat disimpulkan bahwa tidak terdapat autokorelasi.

6. Uji Regresi Berganda

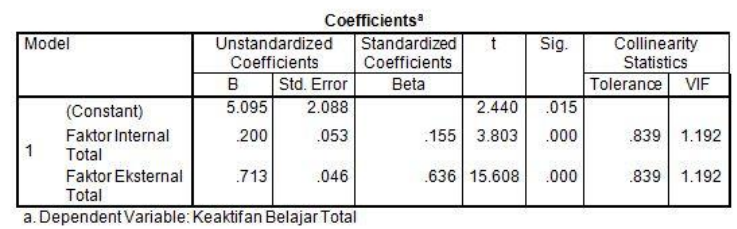

Berdasarkan tabel Output di atas penjelasanya adalah, persamaan regesi linear berganda $\mathrm{Y}=\mathrm{a}+\mathrm{b}_{1} \mathrm{x}_{1}+\mathrm{b}_{2} \mathrm{x}_{2}$ adalah $\mathrm{Y}=5,095+0,200\left(\mathrm{x}_{1}\right)+713\left(\mathrm{x}_{2}\right)$. Persaman regresi ini dapat disimpulkan bahwa, terdapat pengaruh positif secara parsial.

Konstanta $\mathrm{a}=5,095$ menunjukkan bahwa, nilai Keaktifan Belajar (Y) saat ini diasumsikan bernilai 5,095 satuan dengan asumsi variabel Faktor Internal $\left(\mathrm{X}_{1}\right)$ dan Faktor Eksternal $\left(\mathrm{X}_{2}\right)$ bernilai tetap.

Konstanta $\quad \mathrm{b}_{1} \mathrm{x}_{1}=0,200$ menunjukkan bahwa, jika terdapat kenaikan satu-satuan pada variabel Faktor Internal $\left(\mathrm{X}_{1}\right)$ maka nilai Keaktifan Belajar (Y) akan bertambah sebesar 0,200 satuan.

Konstanta $\quad \mathrm{b}_{2} \mathrm{x}_{2}=0,713$ menunjukkan bahwa, jika terdapat kenaikan satu-satuan pada variabel Faktor Eksternal $\left(\mathrm{X}_{2}\right)$ maka nilai Keaktifan Belajar (Y) akan bertambah sebesar 0,713 satuan.

\section{Uji Hipotesis}

"Hipotesis adalah dugaan terhadap hubungan antara dua variabel atau lebih. Atas dasar definisi tersebut dapat diartikan bahwa hipotesis adalah jawaban atau dugaan sementara yang perlu di uji kebenarannya. Hipotesis penelitian di uji dengan menggunakan uji simultan."

Hipotesis yang diajukan dalam pengujian pengaruh secara simultan adalah:

$\mathrm{Ho}_{1} \quad$ : Tidak terdapat pengaruh faktor internal $\left(\mathrm{X}_{1}\right)$ dan faktor eksternal $\left(\mathrm{X}_{2}\right)$ terhadap keaktifan belajar (Y).

$\mathrm{Ha}_{1}$ : $\quad$ Terdapat pengaruh faktor internal $\left(X_{1}\right)$ dan faktor eksternal $\left(X_{2}\right)$ terhadap keaktifan belajar (Y).

\begin{tabular}{|c|c|c|c|c|c|c|}
\hline Mod & & Sum of Squares & df & Mean Square & $\mathrm{F}$ & Sig. \\
\hline \multirow{3}{*}{1} & Regression & 4959.886 & 2 & 2479.943 & \multirow[t]{3}{*}{182.152} & \multirow[t]{3}{*}{$.000^{\circ}$} \\
\hline & Residual & 4819.593 & 354 & \multirow[t]{2}{*}{13.615} & & \\
\hline & Total & 9779.479 & 356 & & & \\
\hline
\end{tabular}

b. Predictors: (Constant), Faktor Eksternal Total, Faktor Internal Total

Melihat tabel Output di atas dapat dijelaskan bahwa, $F_{\text {hitung }} 182,152>\mathrm{F}_{\text {tabel }}$ 3,04 dengan Sig $0,000<0,05$ maka $\mathrm{H}_{0}$ di tolak dan $\mathrm{Ha}$ di terima artinya signifikan dapat dikatakan hipotesis yang telah diajukan terdapat pengaruh positif dan signifikan secara simultan.

\section{Koefisien Determinasi}

"Koefisien determinasi adalah kadar kontribusi variabel bebas terhadap variabel terikat. Koefisien determinasi dilambangkan $\mathrm{R}^{2} . "$

a. Koefisien Koefisien Determinasi Faktor Internal $\left(\mathrm{X}_{1}\right)$ Terhadap Keaktifan Belajar (Y)

\begin{tabular}{l}
\begin{tabular}{|l|c|r|r|r|}
\hline Model & $R$ & R Square & $\begin{array}{c}\text { Adjusted R } \\
\text { Square }\end{array}$ & $\begin{array}{c}\text { Std. Error of the } \\
\text { Estimate }\end{array}$ \\
\hline 1 & $.410^{3}$ & .168 & .166 & 4.787 \\
\hline
\end{tabular} \\
\hline
\end{tabular}

Dari tabel di atas dapat dijelaskan bahwa: Nilai R Square $=0,168$ dapat disimpulkan bahwa, Faktor Internal ( $\left.\mathrm{X}_{1}\right)$ memberikan kontribusi terhadap Keaktifan Belajar (Y) sebesar 16,8\% dan sisanya 83,2\% dipengaruhi oleh faktor lain.

b. Koefisien Determinasi Faktor Eksternal $\left(\mathrm{X}_{2}\right)$ Terhadap Keaktifan Belajar (Y) 


Model Summary
\begin{tabular}{|l|c|r|r|r|}
\hline Model & $R$ & R Square & $\begin{array}{c}\text { Adjusted R } \\
\text { Square }\end{array}$ & $\begin{array}{c}\text { Std. Error of the } \\
\text { Estimate }\end{array}$ \\
\hline 1 & \multicolumn{6}{|c|}{$698^{3}$} & .487 & .486 & 3.759 \\
\hline
\end{tabular}
a. Predictors: (Constant), Faktor Eksternal Total

Dari tabel di atas dapat dijelaskan bahwa:

Nilai R Square $=0,487$ dapat di ambil kesimpulan bahwa, Faktor Eksternal $\left(\mathrm{X}_{2}\right)$ memberikan pengaruh terhadap Keaktifan Belajar (Y) sebesar $48,7 \%$ dan sisanya $51,3 \%$ dipengaruhi oleh faktor lain.

c. Koefisien Determinasi Faktor Internal $\left(\mathrm{X}_{1}\right)$ dan Faktor Eksternal $\left(\mathrm{X}_{2}\right)$, Terhadap Keaktifan Belajar (Y)

Model Summary ${ }^{\circ}$

\begin{tabular}{|l|r|r|r|r|r|}
\hline Model & $R$ & $R$ Square & $\begin{array}{c}\text { Adjusted } R \\
\text { Square }\end{array}$ & $\begin{array}{c}\text { Std. Error of the } \\
\text { Estimate }\end{array}$ & Durbin-Watson \\
\hline 1 & $.712^{3}$ & .507 & .504 & 3.690 & 1.887 \\
\hline
\end{tabular}

b. Dependent Variable: Keaktifan Belajar Total

Tabel tersebut dapat dijelaskan bahwa:

Nilai $\mathrm{R}$ Square $=0,507$ dapat disimpulkan bahwa, Faktor Internal $\left(\mathrm{X}_{1}\right)$ dan Faktor Eksternal $\left(\mathrm{X}_{2}\right)$, Terhadap Keaktifan Belajar (Y) sebesar 50,7\% dan sisanya 49,3\% dipengaruhi oleh faktor lain.

\section{B. Pembahasan}

Berdasarkan hasil penelitian menunjukkan bahwa, Keaktifan Belajar pada mahasiswa tingkat 1 program studi manajemen Universitas Pamulang sudah Sangat Baik ditandai dengan penilaian 15066 dan nilai rata-rata sebesar 4,22. Dan pengaruh secara simultan antara Faktor Internal $\left(\mathrm{X}_{1}\right)$ dan Faktor Eksternal $\left(\mathrm{X}_{2}\right)$ Terhadap Keaktifan Belajar (Y). Hal ini dibuktikan berdasarkan nilai $\mathrm{R}$ Square $=0,507$ dapat disimpulkan bahwa, Faktor Internal $\left(\mathrm{X}_{1}\right)$ dan Faktor Eksternal $\left(\mathrm{X}_{2}\right)$ Terhadap Keaktifan Belajar (Y) sebesar 50,7\% dan sisanya sebesar $49,3 \%$ ada pada faktor lain yang tidak di teliti. Uji hipotesis menunjukkan nilai $\mathrm{F}$ hitung $182,152>\mathrm{F}$ tabel 3,04 atau probabilitas Sig 0,000 $<0,05$ maka $\mathrm{Ho}_{1}$ di tolak dan $\mathrm{Ha}_{1}$ di terima artinya signifikan dengan demikian hipotesis yang diajukan menetapkan ada pengaruh secara bersama-sama antara antara Faktor Internal $\left(\mathrm{X}_{1}\right)$ dan Faktor Eksternal $\left(\mathrm{X}_{2}\right)$ Terhadap Keaktifan Belajar (Y) pada mahasiswa tingkat 1 program studi manajemen Universitas Pamulang. Faktor Internal yang sangat mempengaruhi Keaktifan Belajar mahasiswa adalah
Jasmani dengan penilaian 3055 dan nilai rata-rata sebesar 4,27 dengan keterangan Sangat Baik, Faktor Eksternal yang sangat mempengaruhi Keaktifan Belajar mahasiswa adalah Tempat dengan penilaian 3120 dan niai rata-rata sebesar 4,36 dengan keterangan Sangat Baik.

\section{KESIMPULAN DAN SARAN}

Dari pembahasan yang dilakukan peneliti, peneliti dapat mengambil kesimpulan sebagai berikut:

1. Keaktifan Belajar pada mahasiswa tingkat 1 program studi manajemen Universitas Pamulang sudah Sangat Baik ditandai dengan penilaian 15066 dan nilai rata-rata sebesar 4,22.

2. Pengaruh secara simultan antara Faktor Internal $\left(\mathrm{X}_{1}\right)$ dan Faktor Eksternal $\left(\mathrm{X}_{2}\right)$ Terhadap Keaktifan Belajar (Y). Hal ini dibuktikan berdasarkan nilai $\mathrm{R}$ Square $=0,507$ dapat disimpulkan bahwa, Faktor Internal $\left(\mathrm{X}_{1}\right)$ dan Faktor Eksternal $\left(\mathrm{X}_{2}\right)$ Terhadap Keaktifan Belajar (Y) sebesar $50,7 \%$ dan sisanya $49,3 \%$ ada pada faktor lain yang tidak di teliti. Uji hipotesis menunjukkan nilai $\mathrm{F}$ hitung $182,152>\mathrm{F}$ tabel 3,04 atau probabilitas Sig $0,000<0,05$ maka $\mathrm{Ho}_{1}$ di tolak dan $\mathrm{Ha}_{1}$ di terima artinya signifikan dengan demikian hipotesis yang diajukan menetapkan ada pengaruh secara bersama-sama antara Faktor Internal $\left(\mathrm{X}_{1}\right)$ dan Faktor Eksternal $\left(\mathrm{X}_{2}\right)$ Terhadap Keaktifan Belajar (Y) pada mahasiswa tingkat 1 program studi manajemen Universitas Pamulang.

3. Faktor Internal yang sangat mempengaruhi Keaktifan Belajar mahasiswa adalah Jasmani dengan penilaian 3055 dan nilai rata-rata sebesar 4,27 dengan keterangan Sangat Baik, Faktor Eksternal yang sangat mempengaruhi Keaktifan Belajar mahasiswa adalah Tempat dengan penilaian 3120 dan niai rata-rata sebesar 4,36 dengan keterangan Sangat Baik.

Saran-saran yang dapat peneliti berikan sebagai masukan dalam peningkatan Motivasi Belajar, Minat Belajar, Kesehatan Jasmani, Pembimbing Akademik, Lingkungan Sosial, dan Prestasi Belajar adalah sebagai berikut: 
1. Variabel Faktor Internal $\left(\mathrm{X}_{1}\right)$ perlu peningkatan untuk instrumen no. 9 memperoleh penilaian rata-rata paling rendah dengan nilai 2,36. Pada instrumen ini mahasiswa harus rajin dalam mengerjakan tugas-tugas yang sudah di berikan oleh dosen.

2. Variabel Faktor Belajar $\left(\mathrm{X}_{2}\right)$ perlu peningkatan untuk instrumen no. 5 memperoleh penilaian rata-rata paling rendah dengan nilai 3,83. Pada instrumen ini agar lebih sering mengingatkann temannya agar masuk ke kampus.

3. Variabel Keaktifan Belajar (Y) perlu peningkatan untuk instrumen no. 6 memperoleh penilaian rata-rata paling rendah dengan nilai 3,80. Pada instrumen ini mahasiswa harus aktif jika ada soal hitung-hitungan.

\section{DAFTAR PUSTAKA}

A.M., Sardiman. 2001. Interaksi Dan Motivasi Belajar Mengajar. Jakarta: Raja Grafindo Persada.

Krisnaldy, K., Pasaribu, V. L. D., \& Batubara, A. S. (2020). Analisis Pengaruh Kedisiplinan Terhadap Performa Pegawai Kelurahan Rempoa, Kota Tangerang Selatan. Jurnal Mandiri: Ilmu Pengetahuan, Seni, Dan Teknologi, 4(2), 131-138.

Krisnaldy, K., Pasaribu, V. L. D., \& Senen, S. (2019). Pengaruh Budaya Organisasi, Lingkungan Kerja Dan Iklim Organisasi Terhadap Motivasi Pegawai Serta Dampaknya Terhadap Kepuasan Kerja. Jurnal Semarak, 2(2), 164-183.

Mohamad Surya. 2004. Psikologi Pembelajaran dan Pengajaran. Bandung: Pustaka Bani Quraisy.

Pasaribu, V. L. D., Susanti, F., \& Hartuti, E. T. K. (2019). Memotivasi Siswa dan Siswi SMK Letris Indonesia di Dalam Menentukan Pilihan Untuk Melanjutkan Pendidikan Atau Bekerja Setelah Lulus Sekolah. Jurnal Pengabdian Dharma Laksana, 1(2), 161-172.

Pasaribu, V. L. D., \& Krisnaldy, K. (2018). ANALISIS KEPUASAN JAMA'AH PADA KINERJA DEWAN KEMAKMURAN MASJID AL-HIDAYAH PERIODE TAHUN 2017. KREATIF: Jurnal Ilmiah Prodi Manajemen Universitas Pamulang, 6(4), 41-51.
Pasaribu, V. L. D., Krisnaldy, K., \& Warasto, H. N. (2020). Pengaruh Gaya Kepemimpinan, Disiplin Kerja Dan Kompensasi Terhadap Kinerja Pegawai (Studi kasus kelurahan Pisangan Ciputat). Jurnal Disrupsi Bisnis: Jurnal Ilmiah Prodi Manajemen, Fakultas Ekonomi, Universitas Pamulang, 3(1).

Pasaribu, V. L. D., \& Krisnaldy, K. (2020). PENGARUH GAYA KEPEMIMPINAN, DISIPLIN KERJA DAN KOMPENSASI TERHADAP HASIL KINERJA KARYAWAN KELURAHAN CIPUTAT. PROCEEDINGS UNIVERSITAS PAMULANG, 1(1).

Prabowo, B., Juanda, A., \& Pamungkas, I. B. (2020). PENGARUH PERKEMBANGAN TEKNOLOGI INFORMASI DAN FAKTOR KELUARGA TERHADAP PRESTASI BELAJAR SISWA SEKOLAHDASAR (Study Kasus Di Kecamatan Pondok Betung, Tangerang Selatan). JURNAL

SeMaRaK, 3(1), 60-74.

Qurbani, D., Pamungkas, I. B., \& Sewaka, S. (2020). Faktor-Faktor yang Mempengaruhi Prestasi Belajar Mahasiswa Tingkat 1 Universitas Pamulang Fakultas Ekonomi Program Studi Manajemen Reguler A. JIMF (Jurnal IImiah Manajemen Forkamma), 3(3).

Sugiyono. 2014. Metode Penelitian Pendidikan Pendekatan Kuantitatif, Kualitatif Dan R\&D. Bandung: Alfabeta.

Sugiyono. 2016. Metode Penelitian Kuantitatif Kualitataif dan Kombinasi (Mixed Methods). Bandung: Alfabeta.

WJS. Poerwadarminta. 2002. Kamus Umum Bahasa Indonesia. Jakarta: Balai Pustaka. 